have time not only to read and think about his specialist studies, but also to mix with men studying other subjects than his own and thereby broaden his general intellectual interests and enlarge his outlook". It is an arresting reflection upon present conditions that such a recommendation should be necessary.

The Board further believes that it is of importance to emphasize that industry requires, and can make use of, for administration, research, laboratory and process operations, etc., not one type alone but many types of chemists, chemical assistants, and chemical technicians, whose education and training may vary greatly and proceed along diverse lines. Opportunity and suitable educational facilities should be provided to enable a worker beginning hrs career in any one of the lower grades to pass to a higher grade and to attain the highest qualification and professional position to which he may aspire, and for which he shows himself fitted. For these reasoins, the Board welcomes the Government's intention to establish compulsory part-time education up to the age of eighteen, and suggests that the special requirements of young chemists should, at the minimum schoolleaving age, be reviewed and care taken in assessing their abilities and in giving guidance with regard to their further education and training. This might be done in the larger centres by setting up advisory committees consisting of representatives of the schools, of universities, of technical colleges, of chemists in industry, and of the Royal Institute of Chemistry. Power might also be given to such advisory committees to recommend suitable parttime students for the award of scholarships or bursaries to enable them to continue their education at a university or technical college.

These are sound and practicable suggestions, which clearly ought to be put into operation at the earliest opportunity. 'The same may be said about the Board's views on the technical education of chemical technicians and chemical works operatives, that is, young employees and skilled or semi-skilled craftsmen who require a knowledge of chemistry and chemical technique but in whom no high standard of academic attainment is needed or expected. Even with such men, however, the Board feels quite properly that the standard of education-general, scientific, and technical-should be raised as much as possible, and that this is one of the main reasons, so far as chemical industry is concerned, why the minimum schoolleaving age should be raised and compulsory parttime education introduced.

Two concluding topics treated by the report are the training of chemists in the professional grade, and the supply and training of teachers. On the first, the Board feels that the first three years of a university or higher technical college course should be comparatively free of technology, and that only in the fourth year should technological subjects take first place. On the other hand, during his undergraduate years, the student of chemistry should be encouraged to visit as many industrial works as possible, in order to acquire some insight into the large-scale applications of chemistry and the conversion of laboratory operations into industrial processes. Before the War, vacation courses for undergraduate chemists were arranged by certain manufacturing firms, and the Board hopes that similar facilities, on an increased scale, may be offered by chemical manufacturers after hostilities cease. The Board is also of opinion that it is important to develop much more fully than hitherto the establishment of graduate schools of technological study on lines such as those followed at the Massachusetts Institute of Technology.

Finally, on the supply and training of teachers, the gist of the report is that-particularly in technical colleges-scales of payment are not at present adequate, and that the only way to ensure sufficient teachers of the desired character and calibre is to make the conditions of service sufficiently attractive. That it should be easier to make this recommendation than to implement it is unfortunate, for the provision of the requisite number of competent teachers is patently one of the linchpins of the whole educational vehicle. But experience of the last four or five years has shown that money can always be found when hard necessity calls; and it is for the Chemistry Education Advisory Board and other chemical and scientific bodies to convince the country of the urgent necessity of mobilizing and arming the total strength of Britain's chemical forces.

\section{INDUSTRIAL POLICY AND EMPLOYMENT IN GREAT BRITAIN}

$\mathrm{T}$

HERE is much that is of real interest to scientific workers in the report, "Work: the Future of British Industry", which has recently been prepared by the Sub-Committee on Industry and issued by the Conservative Central Committee on Post-War Problems. In origin and trend, the report is avowedly a party document, but it attempts in the first placeand succeeds in so doing - to show the measure of agreement that already exists on industry and economic policy between the chief political parties in Great Britain. Largely it is a statement of principles, and it clearly owes much to such previous documents as the Unilever paper, "The Problem of Unemployment", the Nuffield College papers on "Employment Policy and Organization of Industry after the War" and "Industry and Education", and sundry others on reconstruction and industrial policy.

The extent to which there is common ground as to the approach to post-war problems and our attitude to them, rather than on the measures by which they are to be solved-for, as will be noted later, the report gives little hint as to a policy-may be illustrated by a few examples. Once again we find emphasized the interdependence of industry and agriculture, the importance of the growth of industrial management as a salaried profession, and of the new educational reforms in widening the sphere of recruitment for such positions as well as in raising the standard of skill. The necessity of developments in technical education is specially stressed; and in welcoming closer collaboration between industry and commerce and the education service, there is a pointed reference to the need to include the universities. 
What is said here on the purpose of industry, not merely as producer of the goods required to raise continuously the standard of living for all, to earn the means of paying for the necessaries we must import from abroad, and as a means of livelihood, but also on its being for millions a large part of life itself, implies an attitude which is the real starting point for all human developments in industry and the creation of the right atmosphere for true efficiency. Recognition that the nature of the work, the mental atmosphere, the material environment, the contacts with fellows, with seniors and with subordinates must necessarily enrich or impoverish the lives and outlook of the workers, and through them the life and outlook of the nation as a whole, is the true starting point for developing co-operation whether through joint production committees or in other ways. Once again, we find a welcome for the 'staff college' idea; and the observations on training for management, health services and welfare, hours of work, status and responsibility should be endorsed by all shades of opinion. Moreover, while emphasizing the place of trade unionism and its value as a training for democracy, there is a timely reminder that trade unions were not established to be the preserve of any one political party.

Again, the report faces the future with emphasis on opportunities rather than on difficulties. The prime need is readiness to pioneer and face risks. It is essential to encourage the spirit of initiative, of adventure, of hope, not to go slow and play for safety. In keeping with this, we find that the report not only recognizes the importance of overthrowing all sectional obstacles to human efficiency and restrictive practices, but also, in keeping with other recent reports, urges the need in many branches of industry for a new awakening to the importance of organized research and to the scale on which British industry must further and utilize the advances of science. A major factor in determining the future prosperity of Great Britain will be the full use of our inventiveness and technical skill. More trained scientific workers, a strong development of scientific research in universities and far greater encouragement and scope for scientific men in industry - all these are urged in the report. Once again it is argued that the manner in which experimental and development work is treated for taxation purposes is restrictive and tends to impede application of results of research to the factory, but the need for change in taxation policy comes second to that for an awakening among those who determine financial policy in industry to the part which science has to play in the future of British industry.

On the question of the relations between government and industry the report recognizes the need for building up a practical system of government, but on the broad question of the structure of industry the report is scarcely as open-minded as, for example, Mr. S. Courtauld in some of his recent utterances, and is inclined to prejudge the issue. In accordance with suggestions in Parliamentary debates and in the Nuffield College paper, it regards new measures for training the staffs of Government departments con- cerned with industry, and especially export problems, as essential, so that they can instinctively appreciate those problems from inside. It calls for dynamic co-operation between industry and Government departments, and looks for a Ministry of Industry and Commerce inspired by a more positive and constructive conception of its duty to help British industry to grow healthily, make good any weaknesses, sell its goods and provide employment. Among its suggestions are a panel of advisers to a Ministry of Industry, chosen from among the best men available in the industrial field, as well as a highly qualified research staff, attached to the Ministry if not to the Cabinet offices, so that, when Government policy is being shaped, expert advice on any relevant aspect can be taken into account.

These suggestions are independent of the general character of industrial enterprise; but there are other comments, for example, on the future of controls and on the location of industry, which represent a large measure of agreement among progressive opinion. The reasons for continuing controls after the War are well formulated, and taken with Sir Stafford Cripps's recent statement and Mr. Bevin's speech to the cotton trade on January 7, should do something to take this question out of the field of faction and place it in its true perspective. In regard to the location of industry, many of the proposals of the Barlow Report are clearly supported. The imperative necessity of ensuring that the national interest is paramount in all decisions in this field, and that it is not obstructed or thwarted by sectional interests, is the crux of the case for the National Industrial Board recommended in that report; although the necessity for central machinery and powers is admitted in veiled terms which do not distinguish between the majority and the minority proposals.

After discussing monopolies, trade associations, etc., the report makes the essential point that is often overlooked in such discussions : technical progress, skilled administration, and good workmanshipthese, and not a now political system, can raise the standard of living. A new political system might, of course, contribute to raise the standard in any one of these three directions. The real question is what forms of organization are most conducive to efficient and successful management in any and in every field of industry.

A welcome feature of the report is the support accorded to international co-operation. In the Committee's view, the greatest single cause of the severe unemployment which afflicted practically every industrial country at some time or other between the two wars was the failure of the nations to diagnose unemployment rightly as a world problem, and to collaborate confidently with each other in policies correctly designed to remedy its deep-seated causes. It should be a prime aim of British policy to ease the way to economic collaboration among all the United Nations in accordance with the fifth point of the Atlantic Charter.

The necessity for new developments of international economic machinery is recognized, as well as the expansion and strengthening of existing institu. 
tions such as the International Labour Office. Further, a new international currency agency is suggested, whatever differences of view exist about the manner and rules of its operation. General stability of exchange-rates is a prime necessity in laying firm foundations for the recovery and continued growth of world trade, and the provision of massive credits for rehabilitation is given strong support.

The report expresses the hope that the United Nations will also put boldly in hand long-term constructive plans for world prosperity. Stable and reasonable prices for primary producers are necessary, not only for the sake of farmers, but also as an insurance against the shocks which widely fluctuating prices of agricultural products cause to trade and unemployment. As the Hot Springs Conference recommended, a body of broad principles should be reached, through international discussion, regarding the planning and structure of international com. modity agreements. The emphasis is laid on regulation, not restriction.

Support is also forthcoming for proposals to raise the economic standards of backward peoples. The awareness of the possibilities in raising standards of living and welfare, undertaken on sound economic and scientific lines, is a welcome feature of the report, which recognizes that the increase in world purchasing power thus created would flow back to become a further safeguard against under-employment in the industrial countries. The report appears to favour entrusting these tasks to international reconstruction and development agencies as visualized by Political and Economic Planning. Here again we find the need for accurate data emphasized, and it is urged that an essential step in stabilizing employment is an international statistical service.

An important section of the report is devoted to export policy in relation to employment. Here, pleading for further government support, the Committee advocates not subsidies but the removal of any handicaps on export business which it is in the power of the government to remove, and the fullest co-operation between industry and government in the examination of acute export problems. The dependence of social security on a pclicy of employment is recognized, as is the value of public works, though here the report is much more guarded than the Unilever statement. Public works should be treated as a buffer against depression, not as a cure for it; but priority should be given to projects making for efficiency, whether of industry, agriculture or transport, or the quality of our people-a Severn bridge, a road bridge over the Forth, port facilities, and school buildings are indicated.

The report, taken as a whole, is characteristic of progressive thought, independent of party, and the measure of agreement thus indicated as to the direction, if not necessarily of the tempo and methods, of advance should help to eliminate faction and facilitate the initiation of some of the large measures immediately required. Moreover, such agreement should at least facilitate the scientific approach to the problems of reconstruction, and help to secure that, whatever action is taken or policies formulated, they are at least in keeping with the demands of the facts which scientific inquiry has brought to light. The Labour Party's adoption of a memorandum on food prepared by Sir John Orr as its own official policy may well be regarded not merely as a sign of a non-partisan approach to this vitally important problem, but also as an indication of the possibility that party programmes and policies may at least start from common ground in the results of impartial scientific investigation of the technical aspects of the problems concerned.

While in this way the scientific method may help to eliminate the demagogue, it must be remembered that the scientific and technical issues, important as. they may be, are, as a rule, only a part of the problem. As to the means of dealing with the social and political aspects, there may well be, and usually are, alternative solutions. Accordingly it is not sufficient, as the Conservative Sub-Committee on Industry has done in this report, to make clear the measure of agreement on objectives. It is necessary for policy also to be formulated, and for the differences between the practical measures proposed by different political parties to be made equally clear. This present report fails to do this, but unless and until it is done (whether for or by the electorate), a democratic system cannot function effectively.

\section{THE BORDERLAND BETWEEN PHYSICS AND MUSIC}

The Physics of Music

By Dr. Alexander Wood. Pp. xii $+256+14$ plates. (London: Methuen and Co., Ltd., 1944.) 2ls. net. R. WOOD is known to many generations of Cambridge physicists as an excellent teacher of acoustics, and to an even wider circle as a writer of text-books on the same subject. In his latest book he is equally successful in "the very interesting borderland between physics and music" in which so much new knowledge has been gained in recent years. $\mathrm{He}$ has written a most useful and valuable book, from which both physicists and musicians can learn a great deal.

The first five chapters expound the general theory of sound, with no very marked emphasis on music, and lead up to a good chapter on the ear and the mechanism of hearing. The next three chapters deal fairly exhaustively with the production of sound by musical instruments-strings, organ pipes, the human voice and orchestral instruments, both wind and percussion. Then come four varied chapters on dissonance and consonance, on scales and temperament, on the mechanical and electrical reproduction of sound, and on the acoustics of halls and concert rooms. This last is a most valuable chapter-or would be if everyone would read it who ought to. For, although the situation has greatly improved of late, many of our auditoria form standing monuments to a want of co-operation between scientific men, musicians and architects. Here Dr. Wood tells us what can be done and what ought to be done. "Probably," he says, "there is no direction in which co-operation between the musician and the scientist is likely to be more fruitful than that of designing auditoria for music," and the same might have been said of rooms for speaking. 